\title{
Effect of Abscisic Acid, Salicylic Acid, Potassium Silicate, and Trichoderma harzianum As Biocontrol Agent to Induce the Tomato Resistance Against Early Blight Disease Caused by Alternaria solani
}

\author{
Ibrahim A. Adss ${ }^{1}$, Ghoname. M. Amer ${ }^{2}$ and Shokry R. Bayoumy ${ }^{1}$ and Asia. R. Eid ${ }^{2}$
}

\begin{abstract}
In the present study and under greenhouse conditions, tomato plants cv. Albium, grown in potted soil inoculated with the early blight fungus $A$. solani, were treated with abscisic acid (ABA), salicylic acid (SA), and potassium silicate (PS) abiotic inducers, singly, and in combination with the biotic inducer Trichoderma harzianum. The different tested inducers significantly decreased the intensity (severity) of early blight disease on tomato, as well as some growth characteristics, photosynthetic capacity, defense-related enzymes and expression analysis of the PR1, PR3 and PR5 genes using Real Time-q PCR. PS+ Trichoderma showed the lowest disease intensity, followed by ABA+ Trichoderma, and Trichoderma treatment had the highest disease intensity when compared to untreated inoculated control. PS + Trichoderma, ABA+ Trichoderma, and SA+ Trichoderma were also the most effective for the best growth characteristics (fresh shoot, dry shoot, fresh root, dry root weight, and total fruits weight/plant). Photosynthetic pigment content was significantly increased with all treatments by chemical inducer and T. harzianum compared with A. solani treatment. PS + Trichoderma was the most effective and significantly enhanced chlorophyll " $\mathrm{A}$ " and chlorophyll "B"content comparing with the A. solani treatment, while, the highest level of carotene content was observed with alt+ABA+ Trichoderma treatment at 2days post inoculation. Peroxidase (POD), polyphenol oxidase (PPO) and Phenylalanine Ammonia-Lyase (PAL) enzymes activity and PR1, PR2 and PR5 gene expressions were significantly increased in all treatments with chemical inducer comparing with the treatment by A.solani, In addition to the treatment by chemical inducer combined with Trichoderma were the most effective compared with chemical inducer alone. The maximum POD, PAL activities and PR1gene expression were observed with alt+PS + Trichoderma followed by alt+ABA+ Trichoderma while, PR2, PR5 gene expressions and POD activity reached the highest level with alt+PS+ Trichoderma followed by alt+SA+ Trichoderma and alt+ABA+ Trichoderma. Trichoderma was of the highest rate of the number of $\mathrm{cfu}$ in treatment with alt+PS+ Trichoderma with cfu was $5.9 \times 10$, while the number of $\mathrm{cfu}$ in treatment with alt+ABA + Trichoderma was $3.77 \times 10^{7}$ and the treatment with alt+SA + Trichoderma was 3.68 $\mathbf{x 1 0}$.
\end{abstract}

Key words: Tomato, Early blight, Alternaria solani, Trichoderma harzianum, Chemical inducer, enzymes, gene expressions.

\section{INTRODUCTION}

Tomato (Lycopersicon esculentum Mill.) is one of the most widespread and popular vegetables in the world. It ranks second in the economic importance after potato in many countries (Prajapati et al., 2014). Tomato early blight caused by the fungus Alternaria solani is economically important tomato disease in several parts of the world (Ali et al., 2016). Infection of tomato plants by the early blight fungus can lead to great losses in crop yield due to damaging leaves and fruits (Chaerani et al., 2007 and EL-Tanany et al., 2018). Use of fungicides is considered the shortest way to obtain efficient results for disease management. However applications of fungicides have hazard effect on human and animal health. Therefore, more balanced, cost effective and eco-friendly approaches were searched and by farmers. Several investigators indicated that certain biotic and abiotic inducers have potentiality to control plant diseases (Anand et al., 2009a and Simonetti et al., 2012). Biological control using antimicrobials, resistance promoters and growth promoters offered good alternatives in controlling plant pathogens (Chandrashekara et al., 2012 and EL-Tanany et al., 2018). Trichoderma spp use as biocontrol agents due to their ability to antagonize the pathogens of plant (Harman, 2006), to induce plant defense responses against pathogens, with beneficial effects on plant growth and development (Harman et al., 2004). Recently, researchers have turned to activate the systemic induced resistance (SIR) of plants using some chemical inducers, such salicylic acid, as this substance enhance the same physiological and biochemical changes in plants as do systemic active biological resistance (El-Shennawy and Abd El-All, 2018). Also, potassium silicate is used as a silicon source and contains small amounts of potassium that can improve environmental stress tolerance and increase crop productivity (Tarabih, et al., 2014, Talebi et al., 2015 and Abou-El-Hassan et al., 2020). Abscisic acid

DOI: 10.21608/asejaiqjsae.2021.196416

"Division of Genetics, Faculty of Agriculture, Damanhur University, Al-Beheira, Egypt

${ }^{2}$ Division of Plant pathology, Faculty of Agriculture, Damanhur University, Al-Beheira, Egypt

Corresponding Author: adssibrahim@agr.dmu.edu.eg

Received August 20, 2021, Accepted, September 26, 2021. 
effectively reduced early blight (Alternaria solani) severity in tomato plants (Song et al., 2011). On the other hand, during host-pathogen interaction abscisic acid is involved in signal transduction pathways to activate the defense genes against plant cell membrane damage during host-pathogen interaction (Adie et al., 2007; Lee and Luan, 2012; Nassar and Adss, 2016). ELTanany et al., 2018, Khalil and Adbelghany, 2021and Prakash et al.,2021. found that, treating tomato plants with abscisic acid, salicylic acid and Trichoderma before inoculation with $A$. solani increased the activities of the plant defense-related enzymes such phenylalanine ammonia-lyase, polyphenol oxidase and peroxidase and reduced the rates of leaf infection and disease index. The gene of PR1 expression was upregulated in leaves were treated by salacylic acid and absesic acid at one day after of inoculation with alternaria solani, which confirms the role of salicylic acid and abscisic acid in systemic acquired resistance( Prakash et al.,2021). the Arabidopsis were high resistant to infection with Golovinomyces cichoracearum than control plants when treated with $\mathrm{Si}$, and corresponded with higher expressions of PR1, PR2 and PR5 defense genes (Vivancos et al., 2015). The aim of this study determination the effect of abscisic acid, salicylic acid, potassium silicate, and Trichoderma harzianum as Biocontrol agent to induce the tomato resistance against early blight disease caused by Alternaria solani.

\section{MATERIALS AND METHODS}

\section{Plant materials:}

Tomato seedlings cv. Albium were surface sterilized for 5 minutes in $1 \%$ sodium hypochlorite (from Chlorax ${ }^{\circledR} 15$ precent) and then washed three times with sterilized water. Seedlings were planted in autoclavesterilized peat moss- in $30-\mathrm{cm}$-diameter plastic pots (one seedling per pot). Fertilizers and irrigation were applied according to the normal greenhouse production program for tomato.

\section{Alternaria solani inoculum preparation and inoculation:}

Tomato plants showing the early blight symptoms were collected from commercial tomato fields in ElBehera Governorate, Egypt and the causal fungus . A. solani isolate was isolated from early blight lesions on leaf sections. The isolate was kept at $20^{\circ} \mathrm{C}$ for 7 days on PDA. Cultures were grown on PDA at $23-25{ }^{\circ} \mathrm{C}$ for 6 days under near UV light $(310-400 \mathrm{~nm})$ with $16 \mathrm{~h}$ to induce sporulation. Conidia were collected on plates that had been washed in sterile water. On a hemocytometer, the spore suspension concentration was adjusted to $10^{6}$ spore/ $\mathrm{ml}^{-1}$. Spraying 45 -day-old tomato plants, cv. albium, with the spore suspension was conducted independently (Bokshi et al., 2003). The plants were then covered in clear plastic bags for 24 hours to promote humidity (>95\%) and enable fungal infection and kept under. Standard greenhouse condition at a temperature of $26^{\circ} \mathrm{C}$ (Bokshi et al., 2003).

\section{Chemical inducers:}

Absesic acid (ABA> $98 \%$ purity), Potassium silicate (PS> $98 \%$ purity), and salicylic acid (SA> $98 \%$ purity), were obtained from Sigma-Aldrich, P2126 were purchased from local supplier and the shown concentrations were prepared in sterile distilled water were $10 \mu \mathrm{M}, 5 \mathrm{~g} / \mathrm{l}, 2 \mu \mathrm{M}$,respectively. Chemical inducers were sprayed before one week of inoculation

\section{Trichoderma inoculum:}

Cultures of Trichoderma harzianum was obtained from plant pathology department, faculty of agriculture, Damanhour university, kept on were kept on PDA media and stored at $4{ }^{\circ} \mathrm{C}$ for later use. One week before Alternaria solani inoculation, the soil was treated by applying $50 \mathrm{~mL}$ of Trichoderma from chosen tomato fields at a concentration of $108 \mathrm{cfu} / \mathrm{ml}$.

\section{The treatments:}

Four replicate pots, each with single tomato plant $\mathrm{cv}$. albium were prepared for each treatment and the conducted treatments were as follows: Uninfected untreated plants (control), untreated inoculated control (infection), Alternaria solani+Trichoderma harzianum (alt+Trichoderma), Alternaria solani + abscisic acid (alt+ABA), Alternaria solani $+\mathrm{ABA}+\mathrm{T}$. harzianum (alt+ABA+Trichoderma), Alternaria solani +Potassium silicate (alt+PS), Alternaria solani +Potassium silicate $+\mathrm{T}$. harzianum (alt+PS+ Trichoderma), Alternaria solani + salicylic acid (alt+SA) and Alternaria solani $+\mathrm{SA}+\mathrm{T}$. harzianum (alt+SA+ Trichoderma).

\section{Disease assessment:}

After 15 days of inoculation, the infected plants were examined and rated using Pandey and Pandey (2002) scale with 0-5 numerical values as follows: $0=$ Disease free, $1=1-10 \%$ infected leaf area, $2=11-25 \%$ infected leaf area, $3=26-50 \%$ infected leaf area, $4=51$ $75 \%$ infected leaf area, $5=>76 \%$ infected leaf area. Then, disease intensity (severity). was calculated according to Rodríguez et al. (2007) using the following equation:

$$
\text { DS \% }=\{\Sigma(\mathbf{N} \times \mathbf{V}) /(\mathbf{N} \times \mathbf{S})\} \times \mathbf{1 0 0}
$$

Where, $\mathrm{N}=$ Number of leaves in each category, $\mathrm{V}=$ Numerical value of infected leaves, and $S=$ Maximum numerical value/grade

\section{Determination of the defense-related enzymes activity:}

The defense-related enzymes; peroxidase (POD), phenylalanine ammonia lyase (PAL), and polyphenol 
oxidase (PPO) activities were evaluated in plants after $0,1,2,4,8,15$ days of $\mathrm{A}$. solani inoculation

\section{a- Peroxidase (POD) activity:}

One gram of tomato leaflets taken from the top six leaves was homogenized in $2 \mathrm{ml}$ of $0.1 \mathrm{M}$ sodium phosphate buffer $(\mathrm{pH} 6.5)$ at $4{ }^{0} \mathrm{C}$. At $10,000 \mathrm{rpm}$ the homogenate was centrifuged for $15 \mathrm{~min}$ at $4{ }^{\circ} \mathrm{C}$. the activity of POD enzyme was estimate in supernatant. The reaction was contained $1.5 \mathrm{ml}$ of pyrogallol $(0.05$ M), $0.5 \mathrm{ml}$ of $\mathrm{H} 2 \mathrm{O} 2(1 \%)$ and $0.5 \mathrm{ml}$ of enzyme. The reaction was incubated at $28 \pm 2{ }^{\circ} \mathrm{C}$. The reaction's absorbance was measured every $20 \mathrm{~s}$ interval for 3 mins at $420 \mathrm{~nm}$.

(Jenway UV/VIS spectrophotometer, Model 6305, Bibby Scientific Limited, Staffordshire, UK). a boiled enzyme was prepared to use a control. The POD activity was expressed as a change in absorbance of the reaction mixture min-1 g-1 of fresh tissue (Hammerschmidt and Kuc, 1982).

\section{b- Polyphenol oxidase (PPO) activity:}

One gram of tomato leaflets taken from the top six leaves was homogenized in A $2 \mathrm{ml}$ sodium phosphate buffer $(0.1 \mathrm{M}) \quad(\mathrm{pH}$ 6.5). The homogenate was centrifuged (Universal 32R, Hettich Centrifuge model D-78532, Germany) at 10,000 rpm for 15 minutes at 4 ${ }^{\circ} \mathrm{C}$, and the supernatant was utilised as a crude enzyme. Polyphenol oxidase activity was determined using a mixture of $1.5 \mathrm{ml}$ phosphate buffer, 2001 enzyme, and 2001 catechol $(0.01 \mathrm{M})$. After 2 minutes at room temperature, the absorbance of the reaction mixture was measured at $495 \mathrm{~nm}$ spectrophotometer (Jenway UV/VIS, Model 6305, Bibby Scientific Limited, Staffordshire, UK). Changes in absorbance were measured every 30 seconds for 2 minutes, and the activity was expressedas a change in absorbance min$1 \mathrm{~g}-1$ of fresh tissue. (Mayer et al., 1965).

\section{c- Phenylalanine Ammonia-Lyase (PAL) Activity:}

According to Dickerson and colleagues (1984), A 2mercaptoethanol (1.4 $\mathrm{mM})$ and insoluble polyvinylpyrrolidone (PVP) in $3 \mathrm{ml}$ of ice-cold sodium borate buffer $(0.1 \mathrm{M}) \mathrm{pH} 7.0(0.1 \mathrm{~g})$ A total of 1 gram of leaf was homogenized. The extract was filtered through cheese cloth at $4{ }^{\circ} \mathrm{C}$, and the filtrate was centrifuged for 15 minutes at 15,000 g. (Universal 32R, Hettich Centrifuge model D-78532, Germany). The supernatant was used as crude enzyme. A $0.4 \mathrm{ml}$ of enzyme extract was incubated with $0.5 \mathrm{ml}$ of borate buffer $(0.1 \mathrm{M}) \mathrm{pH}$ 8.8 and $0.5 \mathrm{ml}$ of L-phenylalanine $(12 \mathrm{mM})$ for 30 minutes at $30{ }^{\circ} \mathrm{C}$ The rate of conversion of $\mathrm{L}$ phenylalanine to trans-cinnamic acid at $290 \mathrm{~nm}$ was used to determine the phenylalanine ammonia-lyase activity by spectrophotometer (Bibby Scientific Limited, Staffordshire, UK, Jenway UV/VIS, Model
6305). The enzyme's activity was calculated in mol trans-cinnamic acid min-1g-1 fresh weight (Dickerson and colleagues, 1984).

\section{Trichoderma density:}

according to Hirte (1969) the dilution plate count technique was applied to determinate the populations of Trichoderma in soil after five weeks of plant inoculation plants with Trichoderma in the previous experiment. Soil suspension, dilution and aliquot for Trichoderma counts to estimate the adequate soil suspension, dilution and aliquots to be added to the culture medium, soil samples were weighed $(10 \mathrm{~g})$, transferred to $100 \mathrm{~mL}$ of distilled and sterile water, and mixed in a rotary shaking machine (260 rpm) for homogenization during $30 \mathrm{~min}$. The soil suspension was diluted from $10^{-1}$ to $10^{-6}$, and an aliquot $(50,100,200,400,800$ and $1000 \mu \mathrm{L})$ from each dilution was transferred to the appropriate culture medium. Two Petri dishes per sample, containing 10 $\mathrm{mL}$ of each culture medium, were incubated 7 days at $25{ }^{\circ} \mathrm{C}$, with $8 \mathrm{~h}$ of light. The number of colons forming units per gram of dry soil (CFU) was calculated after this period.

\section{Assessment of tomato growth parameter:}

At the end of the conducted experiment, seven weeks after inoculation plants were uprooted and the following growth parameters were recorded:

$\square$ Shoot fresh weight (g), Shoot dry weight (g), Root fresh weight $(\mathrm{g})$, Root dry weight $(\mathrm{g})$, Total fruit weight/plant $(\mathrm{g})$.

\section{Determination of photosynthetic pigments:}

Fresh leaflet samples from the top six leaves were gathered from all tomato treatments to determine photosynthetic pigments according to Wintermans and De Mots (1965). In a pestle and mortar, half-gram fresh leaves were pulverized and extracted in $15 \mathrm{ml}$ of $80 \%$ acetone $(1: 100 \mathrm{w} / \mathrm{v})$ and $0.5 \mathrm{~g}$ calcium carbonate. The mixture was filtered using a glass funnel, and the residue was washed with a little amount of acetone until it reached $25 \mathrm{ml}$. For chlorophyll A, chlorophyll B, and carotene, the optical density (O.D) of a constant volume of filtrate was estimated at wave lengths of $662 \mathrm{~nm}, 644$ $\mathrm{nm}$, and $440 \mathrm{~nm}$, respectively. Three times the experiment was carried out. The following equations were used:

Chl.A = 9.784 E.662 - 0.99 E.644 = mg/L, Chl.B = 21.426 E. $644-4.65$ E.662 $=\mathrm{mg} / \mathrm{L}$

Carotene $=4.695$ E.440 $-0.268($ Chl.A - Chl.B $)=$ $\mathrm{mg} / \mathrm{L}$, where, E. = Optical density at the wavelength indicated. 
10. Expression analysis of the PR1, PR3 and PR5 genes using Real Time-q PCR:

Total RNA was isolated from leaf tissues sampled after $0,1,3,5,10,15$ and 20 dpi post inoculation using BioTeke Corporation RNA Isolation kit according to the manufacturer's protocol. cDNA was synthesized from total RNA using dNTPS, poly $\mathrm{T}$ primer, and reverse transcriptase enzyme (Fermentas, USA) according to the standard protocol. QRT-PCR was conducted for PR1, PR3 and PR5 genes. The actin gene of tomato used as reference gene (Molinari and Leonetti., 2019)

The following primers were used in the RT-PCR reaction: PR3 (Molinari and Leonetti., 2019), F-5'AACTATGGGCCATGTGGAAGA -3', R-5'GGCTTTGGGGATTGAGGAG -3', PR5 (Molinari and Leonetti., 2019), GCAACAACTGTCCATACACC $-3^{\prime}, \quad \mathrm{R}-5^{\prime}-$ AGACTCCACCACAATCACC -3', PPO (Goel et al., 2017), F-5'- CATGCTCTTGATGAGGCGTA -3', R-5'CCATCTATGGAACGGGAAGA -3', Actin (Molinari and Leonetti., 2019), F-5'GATACCTGCAGCTTCCATACC $-3^{\prime}, \quad \mathrm{R}$ 5'GCTTTGCCGCATGCCATTCT -3'. The Real-Time PCR Reaction $(25 \mu \mathrm{l})$ contained $12.5 \mu \mathrm{l}$ of $2 \times$ Quantitech SYBR@ Green RT Mix (Fermentas, USA), $1 \mu \mathrm{l}$ of $10 \mathrm{pmol} / \mu \mathrm{l}$ of each primer, $1 \mu \mathrm{l}$ of template cDNA (50 ng), and $9.5 \mu \mathrm{l}$ of RNase free water. The PCR reaction was conducted according Chin et al. (2000): initial denaturation for $10 \mathrm{~min}$ at $95^{\circ} \mathrm{C}$ followed by 40 cycles(denaturation for $15 \mathrm{~s}$ at $95^{\circ} \mathrm{C}$ annealing for $30 \mathrm{~s}$ at $60^{\circ} \mathrm{C}$ and extension for $30 \mathrm{~s}$ at $72^{\circ} \mathrm{C}$ and a final extension for $1 \mathrm{o} \min$ at $72^{\circ} \mathrm{C}$. Gene expression relative quantification was determined by the $2^{\Delta \Delta \mathrm{Ct}}$ method (Livak and Schmittgen, 2001). The expression levels of the target genes were normalized relative to Actin gene and relative expression of untreated control plants at each time were set as 1 .

\section{Statistical analysis}

Data collected from the conducted experiments were analyzed by two-way analysis of variance (treatments and times) using SAS version 9.4 (SAS Institute Inc., Cary, NC, USA). Treatments mean were separated by Duncan's multiple range test at 5\% probability. Tukey's HSD test was used to determine the significant differences between means at a probability level of $\leq 0.05$.

\section{RESULTS}

\section{Effect of biotic and biotic inducers on early blight disease severity on tomato:}

Data in Table (1) show the early blight disease intensity (PDI), i.e. severity, on tomato plants 15 days after inoculation; chemical inducers treatments were used alone or in combination with the T. Harzianum has shown to be effective in protecting against $A$. solani. When compared to infection by $A$. solani, the treatment with potassium silicate + Trichoderma was the most efficient, followed by ABA+ Trichoderma in establishing systemic resistance against the early blight.

2. Effect of biotic and abiotic inducers on enhancing defense related enzymes activity in tomato against $A$. soalni under greenhouse conditions

The phenylalanine ammonia-lyase (PAL), polyphenol oxidase (PPO), and peroxidase enzyme (POD) activity were determined in the tomato $\mathrm{cv}$. albium. at $0,1,3,6,9$, and 15 days after inoculation. The tomato plants were treated with ABA, PS, SA, and Trichoderma in combination for one week after inoculation.

POD enzyme activity was significantly increased in all chemical inducer treatments in tomato leaves when compared to the treatment by A. solani alone, and control as shown in fig (1).

Table 1. Effect of certain biotic and abiotic inducers on early blight disease intensity (severity) on tomato cv. albium, 15 days after inoculation with Alternaria solani in pot experiment under greenhouse conditions

\begin{tabular}{cc}
\hline Treatments & Disease severity (\%) \\
\hline Alternaria solani (inoculated untreated control) & $34.71 \pm 2.09^{\mathrm{a}}$ \\
Alternaria solani+ T. harzianum & $29.35 \pm 2.03^{\mathrm{b}}$ \\
Alternaria solani +ABA & $20.36 \pm 2.03^{\mathrm{c}}$ \\
Alternaria solani +ABA+ T. harzianum & $17.27 \pm 0.81^{\mathrm{e}}$ \\
Alternaria solani +Potassium silicate & $18.02 \pm 1.12^{\mathrm{d}}$ \\
Alternaria solani +Potassium silicate +T. harzianum & $13.31 \pm 0.90^{\mathrm{g}}$ \\
Alternaria solani + SA & $20.03 \pm 2.01^{\mathrm{c}}$ \\
Alternaria solani + SA + T. harzianum & $15.35 \pm 0.86^{\mathrm{f}}$ \\
\hline
\end{tabular}

*All data are averages of triplicate measurements \pm standard deviation, means followed by the different letter(s) are significantly different at $\mathrm{p}=0.05$ 


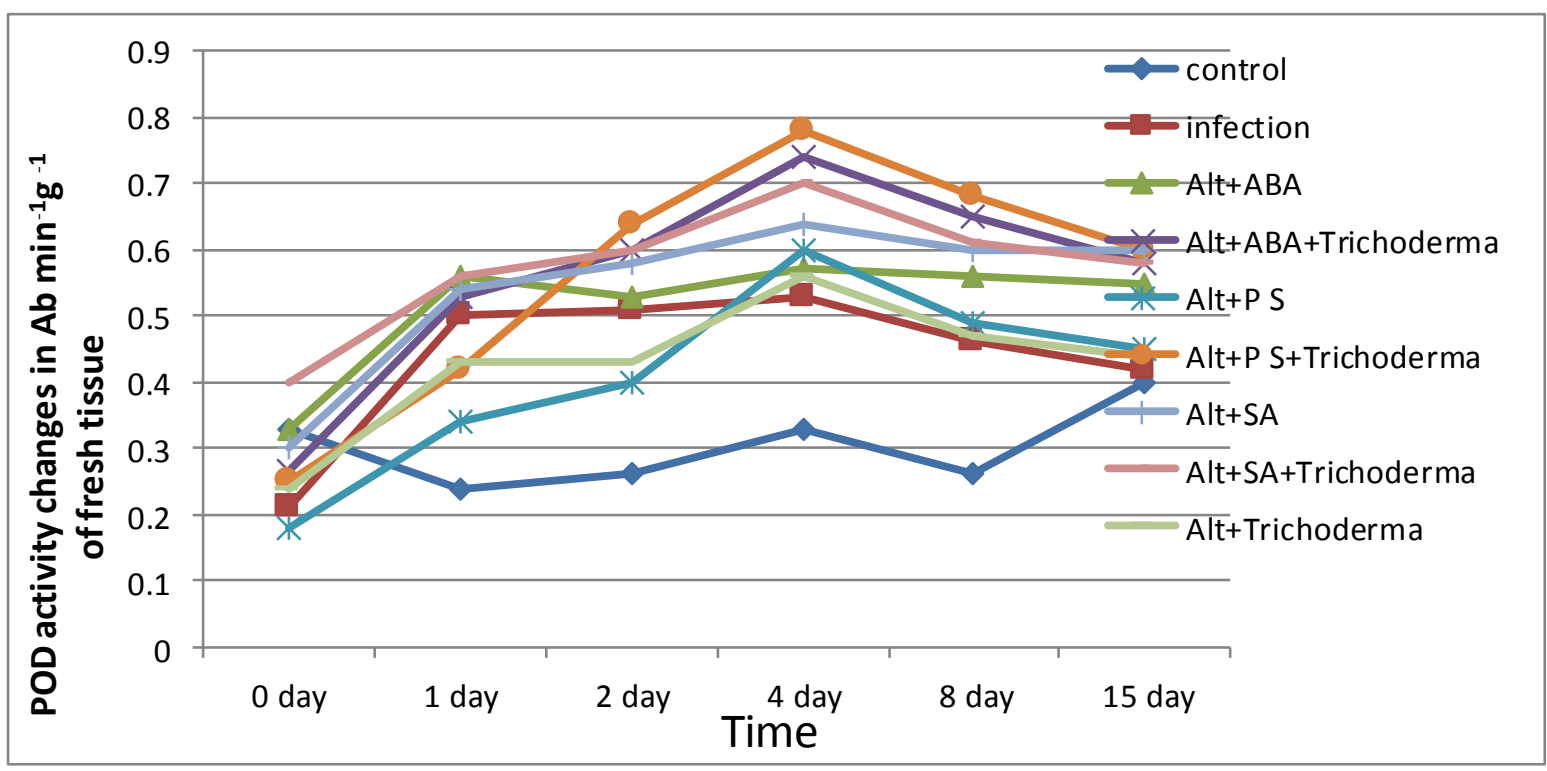

Figure 1. Effect of the treatment with ABA, PS, SA and Trichoderma on POD enzyme activity of tomato leaves infected with $A$. solani

In addition, the treatment by chemical inducer combined with Trichoderma was the most effective when compared to chemical inducer alone. Alt $+\mathrm{P} \mathrm{S}+$ Trichoderma had the highest POD activity, followed by alt+ABA+ Trichoderma and alt+SA+ Trichoderma. POD activity rose over time, peaked at 4 days after inoculation, and then began to diminish. on the other hand, the treatment with SA alone, resulted in the highest POD activity, followed by (ABA) and finally PS.

Meanwhile, Data illustrated in figure (2) revealed that PPO activity rose with time, peaked at 4 days after inoculation in all treatments, and then declined. The chemical inducers considerably boosted enzyme activity in all treatments, while the treatment by chemical inducer combined with Trichoderma were most effective compared with chemical inducer alone. Alt $+\mathrm{P}$ $\mathrm{S}+$ Trichoderma was the most effective, followed by alt+SA+ Trichoderma and alt+ABA+ Trichoderma, all of which increased PPO enzyme activity significantly as compared to the control The treatment with SA alone resulted in the maximum POD activity, followed by PS. Trichoderma therapy, on the other hand, was the least successful when compared to other treatments and when compared to infected plants.
Concerning PAL, data in figure (3) showed that PAL enzyme activity significantly increased in all treatment by chemical inducer on tomato, while the treatment by chemical inducer combined with Trichoderma were most effect compared with chemical inducer alone. Alt+P S +Tichoderma was highest activity followed by alt+ABA+ Trichoderma and alt+SA+ Trichoderma, while the treatment of PS individually was the most effective on increase of PAL activity followed by SA individually. Data also revealed that, the high level of PAL activity was observed from 4 days in the most treatments.

\section{Trichoderma density:}

Results in Table (2) showed the number of Trichoderma harzianum cfu under the effect of chemical inducer on tomato cultivar that infected with $A$ solani. The number of Trichoderma cfu has differed significantly during the period of the tomato cultivar growth. This indicated the success of soil sterilization process and eliminate all the microorganisms. While chemical inducers were applied have increased the number of Trichoderma. Trichoderma was the highest rate of the number of cfu in treatment with alt+PS+ Trichoderma cfu was $5.9 \times 10^{7}$, while the number of $\mathrm{cfu}$ in treatment with alt+ABA + Trichoderma was 3.77 $\mathrm{x} 10^{7}$ and the treatment with alt+SA + Trichoderma was $3.68 \times 10^{7}$ 


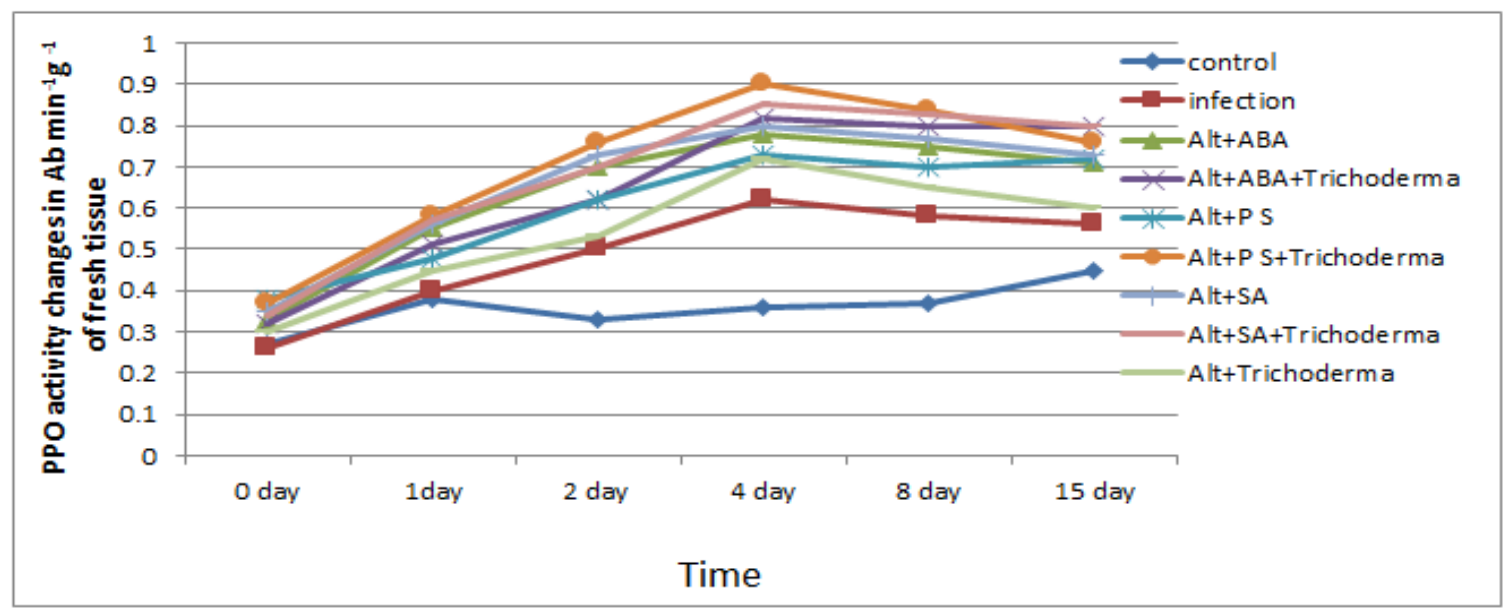

Figure 2: Effect of the treatment with ABA, PS, SA and Trichoderma on PPO enzyme activity of tomato infected with $A$. solani

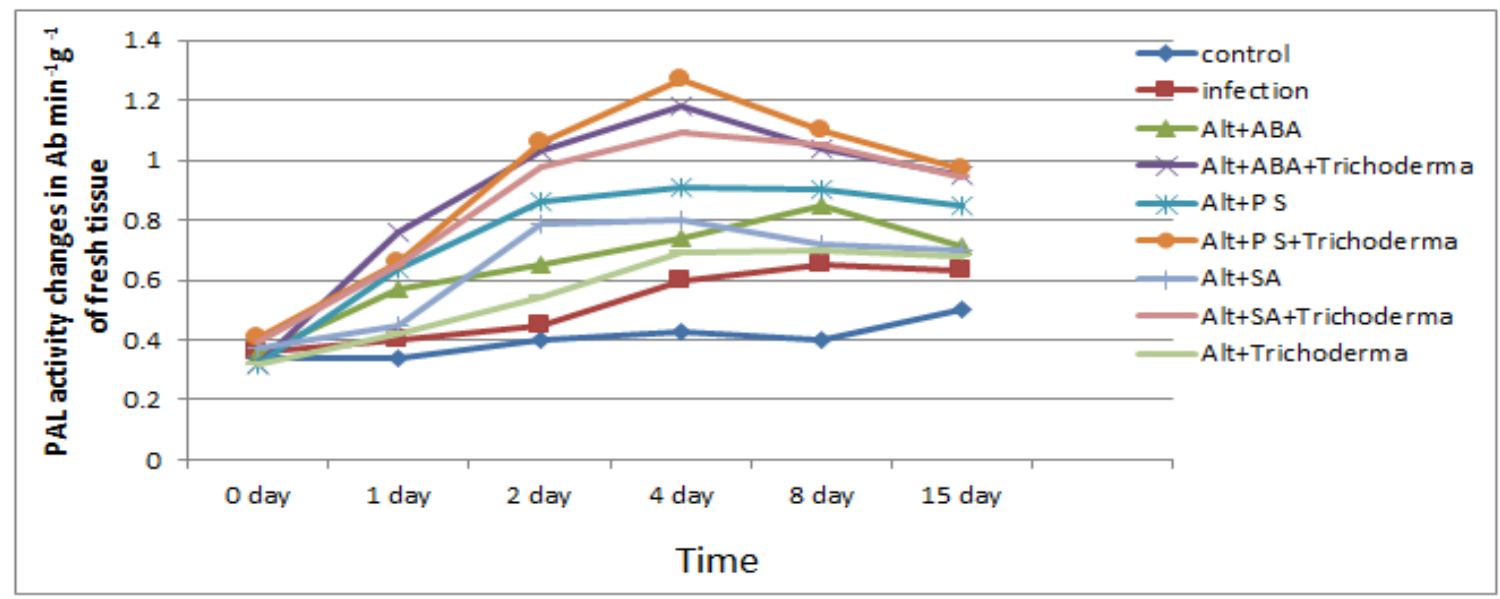

Figure 3: Effect of the treatment with ABA, PS, SA and Trichoderma on PAL enzyme activity of tomato infected with $A$. solani

Table 2. Quantification of Trichoderma harzianum population density (cfu) in soil infested with infested with $A$. solani and cultivated with tomato cv.albium

\begin{tabular}{cc}
\hline Treatments & Trichoderma density (cfu) \\
\hline Alt+ Trichoderma & $3.64 \times 10^{7 \mathrm{c}}$ \\
Alt+ABA + Trichoderma & $3.77 \times 10^{7 \mathrm{~b}}$ \\
Alt+PS+ Trichoderma & $5.9 \times 10^{7 \mathrm{a}}$ \\
Alt+SA+ Trichoderma & $3.68 \times 10^{7 \mathrm{c}}$ \\
\hline
\end{tabular}

Values are average of three replicates. values followed by the different letter(s) are significantly different at $\mathrm{p}=0.05$

4. Effect of biotic and abiotic inducers on tomato growth characteristics in tomato grown in potted soil infested with with $A$. solani:

Data in Table (3) showed the effect of chemical inducer and Trichoderma on tomato growth characteristics (fresh shoot, dry shoot, fresh root, dry root and total fruits weight / plant) in tomato cultivar infected by $A$ solani. There were significant differences between all treatment in the tested growth characteristics The treatment with alt $+\mathrm{P} \mathrm{S}+$ Trichoderma, alt+ABA+ Trichoderma followed by 
alt+SA+ Trichoderma were the most effective and showed the highest growth characteristics values with average of $(191.93 \mathrm{~g}, 24.63 \mathrm{~g}, 22.07 \mathrm{~g}, 4 \mathrm{~g}$ and $69.8 \mathrm{~g})$ and $(180.26 \mathrm{~g}, 21.43 \mathrm{~g}, 20.73 \mathrm{~g}, 3.20 \mathrm{~g}$ and $64.78 \mathrm{~g})$ for the previous characteristics, respectively compared with the other treatments. However, there was no significant differences between alt $\mathrm{ABA}+$ Trichoderma and alt+SA+ Trichoderma in the fresh shoot, dry shoot and fruits weight.

5. Effect of biotic and abiotic inducers on photosynthetic pigments in tomato grown in potted soil infested with by $A$. solani:

The effect of chemical inducer and Trichoderma harzianum on photosynthetic pigments (chlorophyll "A," chlorophyll "B," and carotene) in tomato cultivar was infected by A. solani isolate, is as shown in figs. (4, 5, and 6). When compared to A. solani treatment alone, photosynthetic content was dramatically increased with all chemical inducer and $\mathrm{T}$. harzianum treatments. When compared to the A. solani treatment alone, alt+PS + Trichoderma was the most effective, dramatically increasing (chlorophyll "A" and chlorophyll "B") content. The highest level of chlorophyll "A" and chlorophyll "B" content was observed at 4 days, followed by a drop. At two days after inoculation, the ABA+ Trichoderma treatment had the highest level of carotene concentration. While the PS and ABA treatments were the most successful, when compared to the SA and Trichoderma treatments, they greatly increased the chlorophyll "A," chlorophyll "B," and carotene levels.

6. Quantification of the PR1, PR3 and PR5 gene expression with biotic and abiotic inducers treatment to tomato grown in potted soil infested with $A$. solani.

The expression of PR1 gene was induced by all applied treatments with different relative expression levels among treatments compared with the basal expression level of the infected plant alone. Tomato albium cultivar was used to determine gene expression of PR1, PR3 and PR5. Defense PR genes were evaluated in tomato $0,1,3,6,9$ and $15 \mathrm{~d}$ post inoculations by $A$. solani. Tomato cultivar was treated with ABA, PS, SA individually and in combination with Trichoderma as a biocontrol agent for two weeks after inoculation.

Data illustrated in Fig. (7) showed that PR1 gene expression was increased in all treatments with a chemical inducer of tomato cultivar compared the infection by A. solani alone, while the treatment with chemical inducer combined with Trichoderma were of the highest gene expression compared with chemical inducer alone. Alt $+\mathrm{P} \mathrm{S}+$ Trichoderma showed high gene expression followed by alt+ABA+Trichoderma and alt+SA+ Trichoderma, while the treatment with alt+PS was highest PR1 gene expression followed by alt+ SA in the treatment with chemical inducer alone. Data also revealed that, the highest increase of PR1 gene expression was observed at 8 days.

Table 3.Effect of biotic and abiotic inducers on tomato growth characteristics of tomato albium. cv grown in potted soil infested with $A$. solani

\begin{tabular}{cccccc}
\hline treatments & \multicolumn{2}{c}{ Shoot weight plant(g) } & \multicolumn{2}{c}{ Root weight plant(g) } & $\begin{array}{c}\text { Fruit fresh } \\
\text { weight }(\mathbf{g})\end{array}$ \\
\cline { 2 - 5 } & fresh & Dry & Fresh & Dry & $74.77 \pm 2.21$ \\
Control(non-Infected & $210.72 \pm 1.61$ & $20.72 \pm 1.35$ & $20 \pm 0.36$ & $3.7 \pm 0.20$ & \\
untreated control) & & & & & \\
A. solani & $140.4 \pm 4.90$ & $18.17 \pm 0.25$ & $20.83 \pm 0.29$ & $3.48 \pm 0.13$ & $44.52 \pm 1.1$ \\
Alt+Trichoderma & $160.03 \pm 1.90$ & $19.33 \pm .04$ & $18.40 \pm 0.33$ & $3.22 \pm 0.13$ & $53.48 \pm 2.48$ \\
Alt+ABA & $170.73 \pm 0.32$ & $21.27 \pm 0.40$ & $18.97 \pm 0.68$ & $2.89 \pm 0.13$ & $55.84 \pm 1.38$ \\
Alt+ABA+Trichoderma & $179.6 \pm 2.25$ & $21.33 \pm 0.37$ & $21.1 \pm 0.8$ & $3.88 \pm 0.10$ & $63.6 \pm 0.38$ \\
Alt+PS & $170.17 \pm 0.70$ & $22.33 \pm 0.37$ & $18.27 \pm 0.21$ & $3.3 \pm 0.26$ & $59.73 \pm 0.73$ \\
Alt+PS+ Trichoderma & $191.93 \pm 2.75$ & $24.63 \pm 2.10$ & $22.07 \pm 0.11$ & $4 \pm 0.17$ & $69.8 \pm 0.52$ \\
Alt+SA & $161.03 \pm 1.41$ & $20.54 \pm 0.59$ & $18.50 \pm 0.63$ & $3.06 \pm 0.13$ & $55.48 \pm 2.48$ \\
Alt+SA+ Trichoderma & $180.26 \pm 4.04$ & $21.43 \pm 2.02$ & $20.73 \pm 1.61$ & $3.20 \pm 0.16$ & $64.78 \pm 1.34$ \\
LSD $_{0.05}$ & 4.052 & 0.3502 & 0.220 & 0.102 & 2.09 \\
\hline
\end{tabular}




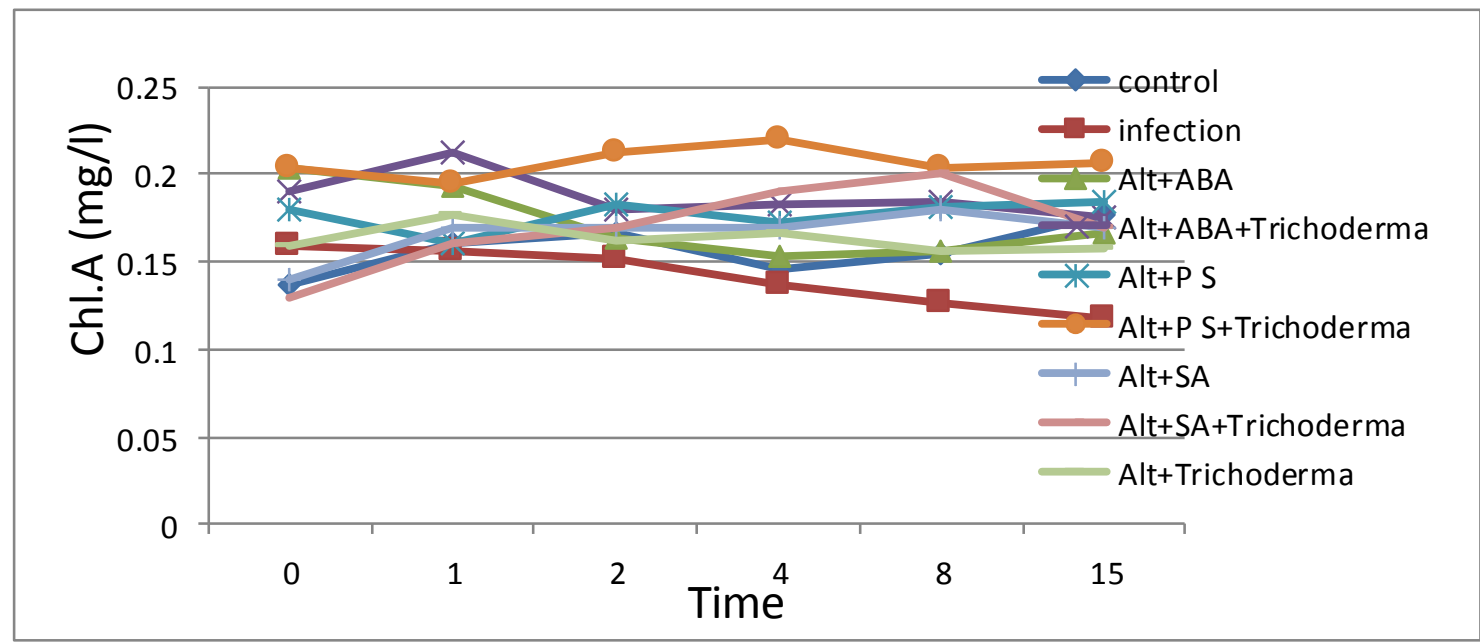

Figure 4. Effect of chemical inducers and Trichoderma on chlorophyll A in tomato cultivar infection with $A$. solani

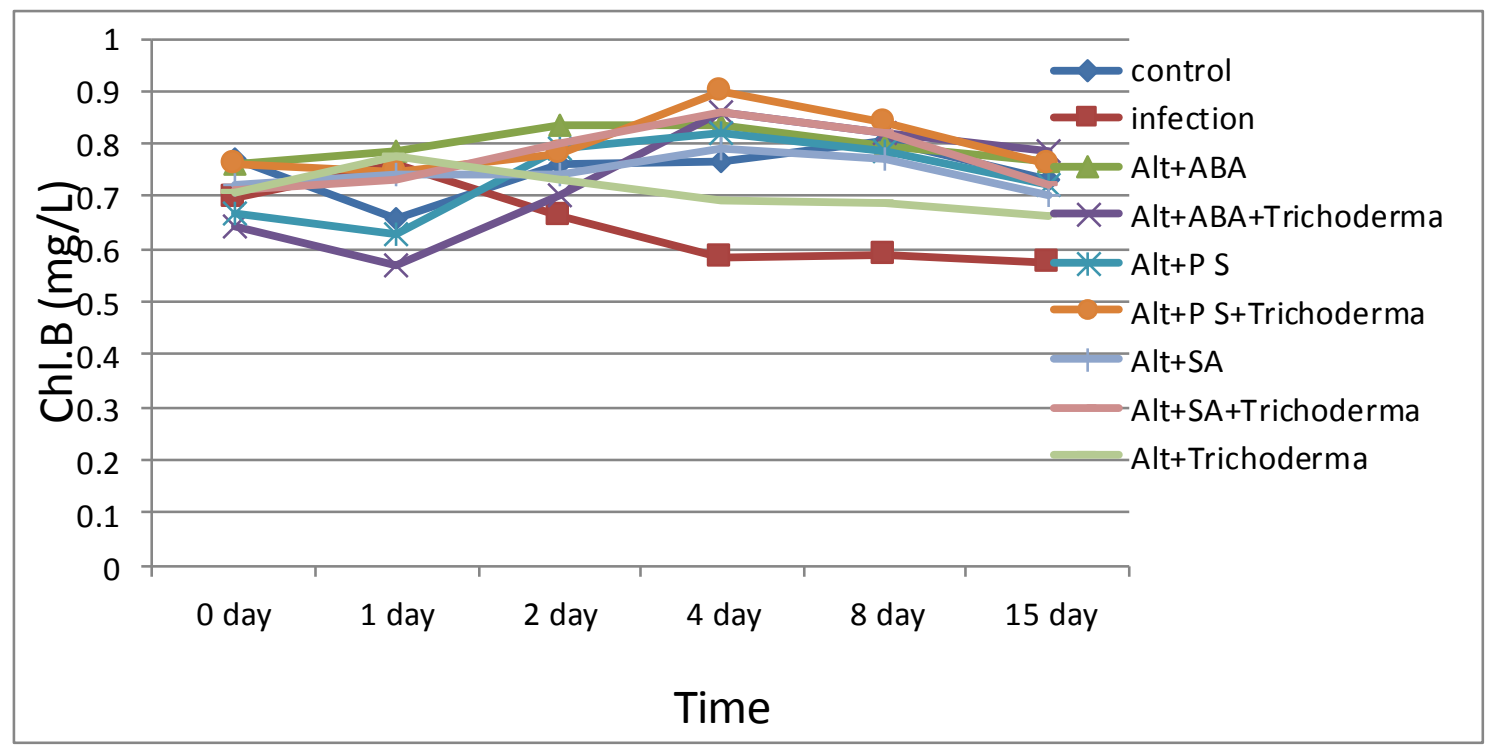

Figure 5. Effect of chemical inducer and Trichoderma on chlorophyll $B$ in tomato cultivar infection with $A$. solani 


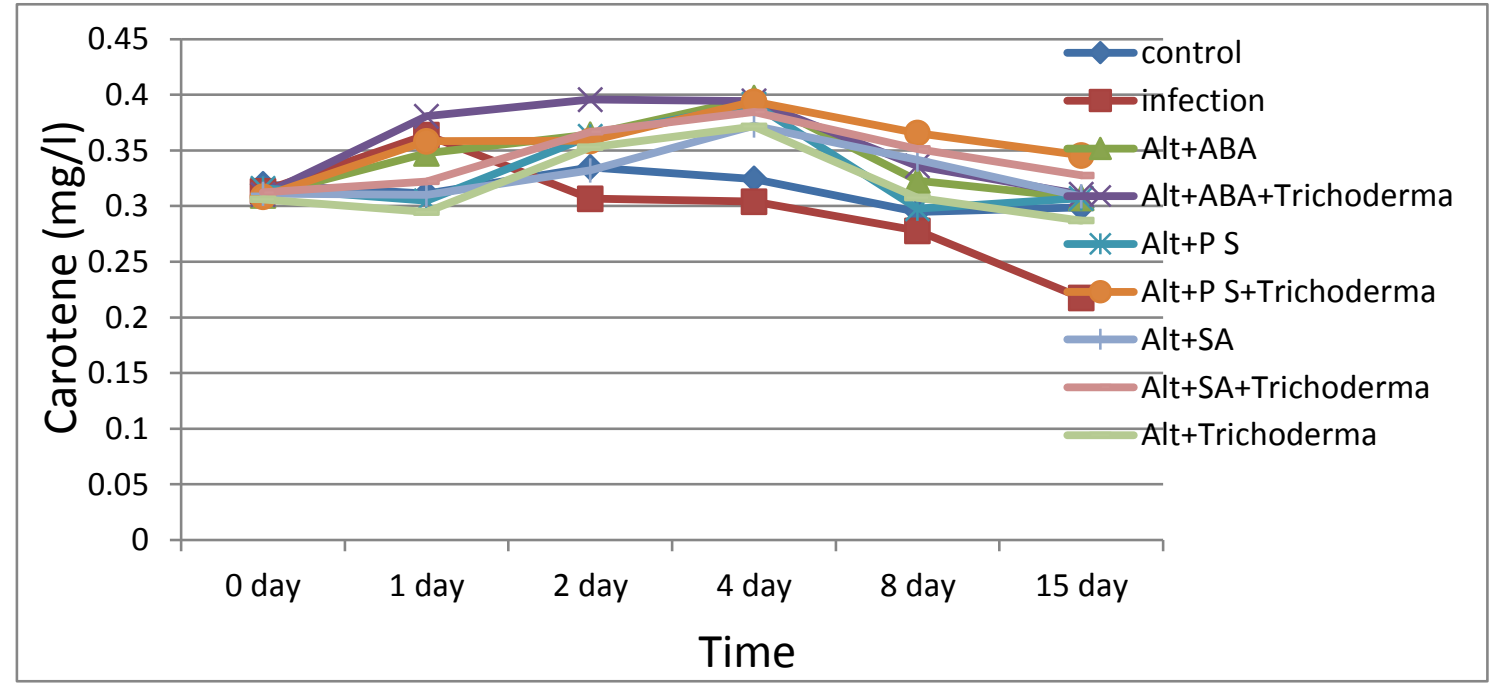

Figure 6. Effect of chemical inducer and Trichoderma carotene contents in tomato cultivar infection with $A$. solani

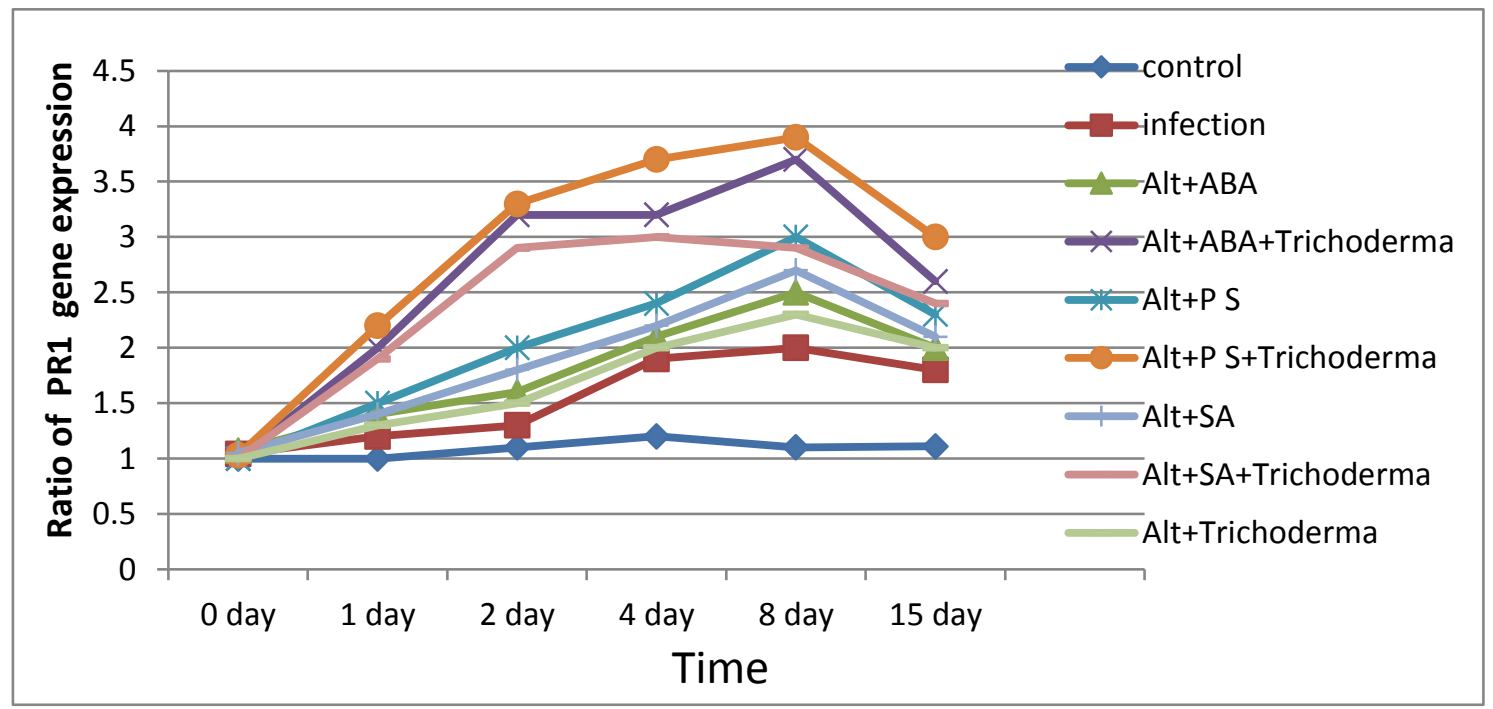

Figure 7.Effect of the treatment with ABA, PS, SA and in combination with Trichoderma on the PR1 gene expression of tomato grown in potted soil infested with $A$. solani

On the other hand, Fig. (8) showed that PR3 gene expression was increased in all treatments with the chemical inducer of tomato cultivar compared the infection by A.solani alone, while the treatment with chemical inducer combined with Trichoderma showed high gene expression compared with chemical inducer alone. Alt $+\mathrm{P} S+$ Trichoderma was of the highest gene expression followed by alt+SA+Trichoderma and alt+ABA+Trichoderma, while the treatment with alt+ABA alone showed high PR3 gene expression followed by alt+PS in the treatment with chemical inducer alone. Data also revealed that, a high increase of PR3 gene expression was observed at 8 days.

Also, Fig. (9) showed that PR5 gene expression was increased in all treatments with the chemical inducer of tomato cultivar compared the infection by A.solani alone, while the treatment with chemical inducer combined with Trichoderma were high gene expression compared with chemical inducer alone. 


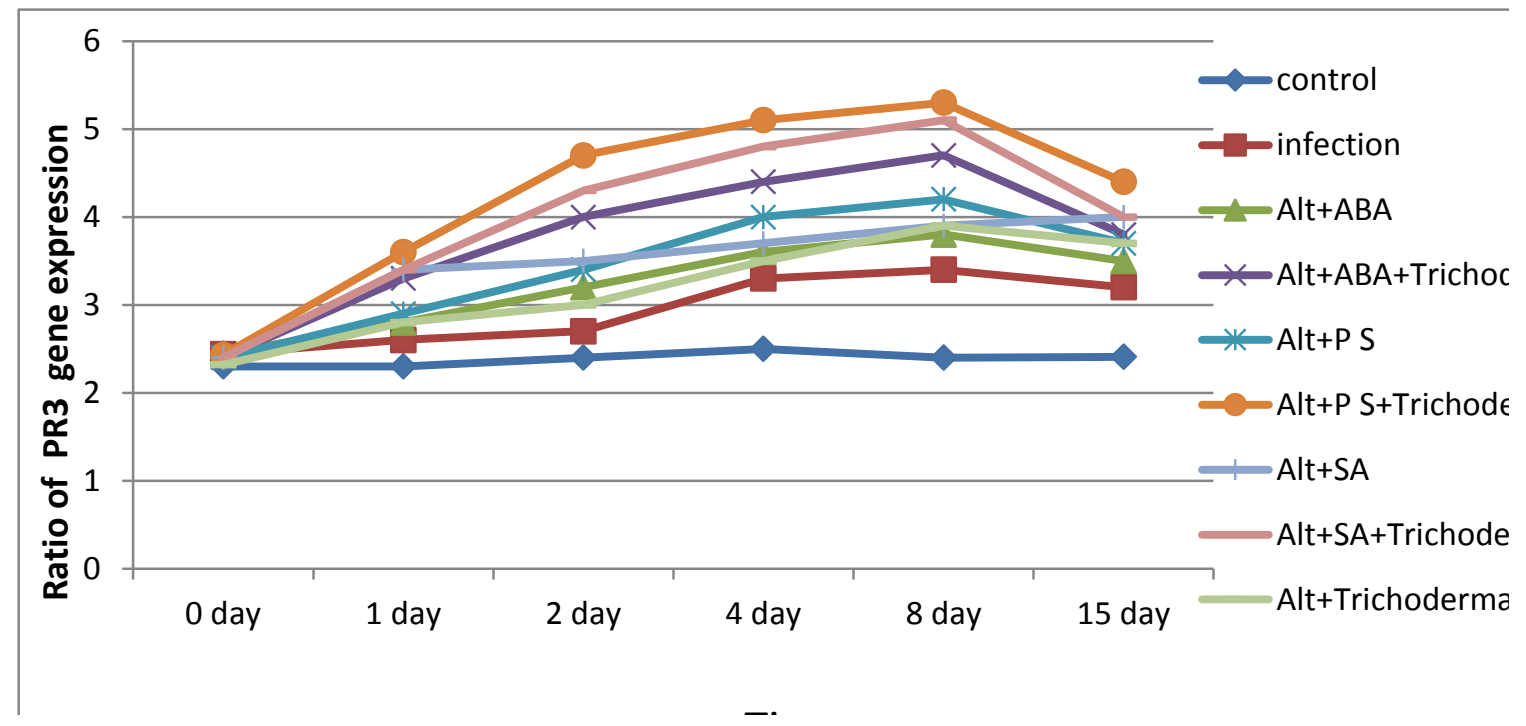

Figure 8. Effect of the treatment with ABA, PS, SA and combination with Trichoderma on the PR3 gene expression of tomato grown in potted soil infested with $A$. solani

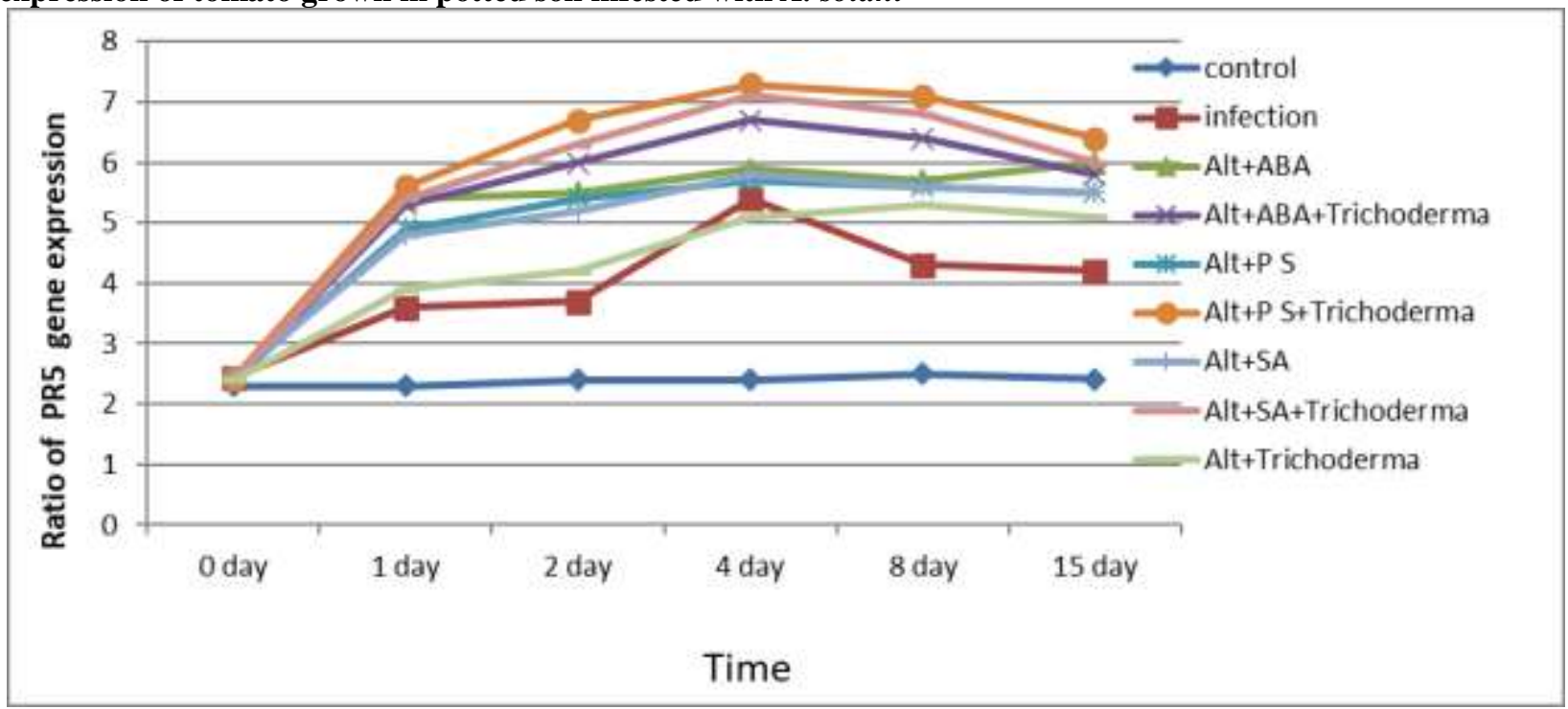

Figure 9. Effect of the treatment with ABA, PS, SA and combination with Trichoderma on the PR5 gene expression of tomato grown in potted soil infested with $A$. solani

Alt+P S +Trichoderma was high gene expression followed by alt+SA+Trichoderma and alt $+\mathrm{ABA}+$ Trichoderma, while the treatment with alt+PS was high PR1 gene expression followed by alt+SA in the treatment with chemical inducer alone. Data also revealed that, a high increase of PR5 gene expression was observed at 4 days. treatment with $\mathrm{ABA}$ alone was high PR3 gene expression followed by PS in the treatment with chemical inducer alone. Data also revealed that, a high increase of PR3 gene expression was observed at 8 days.

\section{DISCUSSION}

Early blight disease of tomato caused by $A$. solani is one of the most serious foliar diseases causing large yield losses especially in plastic houses (Jagadeesh and Jagadeesh, 2009 and EL-Tanany et al., 2018). Fungicides successfully managed the disease; however, fungicides have many hazardous effects on the environment and humans. Plant resistance inducers are among the most important alternative methods for controlling plant diseases that are safe and rapidly biodegradable (Anand et al., 2009a, Ragab et al., 2009 and Simonetti et al., 2012). On the basis of the results 
obtained in the present study inducer treatments when used individually or in combination with the Trichoderma showed significant protective effects against $A$. solani in pot experiment under greenhouse conditions. The treatment with Potassium silicate (PS)+ Trichoderma was the most effective, followed by $\mathrm{ABA}+$ Trichoderma in decreasing PDI of early blight on tomato by inducing systemic resistance against the Early Blight compared with infection with $A$. solani alone and control. These findings were in harmony with reports published by EL-Tanany et al. (2018), Abou-ElHassan et al. (2020) and Prakash et al. (2020) . Potassium silicate could increase the concentration of antifungal compounds such as increase the concentration of phenolic compounds which leads to decrease disease incidence mechanisms (Van Bockhaven et al., 2013 and Sakr, 2016). Also, Silicon has offered protection against fungal diseases by strengthening cell walls which make it difficult to penetrate and colonize the plant by pathogens where, the effectiveness of silicon is due to the physical barrier formed by the deposition of silicon under the cuticle (Keller et al., 2015). Exogenous ABA, on the other hand, could improve disease resistance against $A$. solani infection in tomatoes by activating defense genes and increasing defense-related enzyme activity (Song et al.,2011, EL-Argawy et a.l,2017 and Prakash et al.,2021).

Trichoderma fungal species are known to be effective in reducing pathogenic fungi by generating metabolites derived from cyclopentenone, which have an antagonistic effect on the pathogen (George et al., 1977 and Strunz et al., 1977). Several investigators have noted that fungi belonging to the genus Trichoderma have antifungal properties, which may be attributed to stimulation of anti-pathogen chemicals or the ability to wrap around the pathogen and create aspirin on its surface. In addition, most antagonistic fungi produce a variety of enzymes that break down the pathogen's cell wall, as well as medications (Inbar et al., 1998; Chet et al., 1998). Trichoderma spp use as biocontrol agents due to their ability to regulated the expression level of some PR-protein genes i.e., PR-1 and PR-5 under infected by Alternaria solani (Selim, 2015) and improve the efficiency of photosynthetic and respiratory activity, by reprogramming plant gene expression (Mastouri et al. (2010)

The POD, PPO, and PAL activities significantly increased in all treatments with chemical inducer and Trichoderma of tomato fruits when compared to the treatment with untreated inoculated control(infected) and healthy plant(control). In addition, the treatment with chemical inducer combined with Trichoderma was the most effective when compared to chemical inducer and Trichoderma. The maximum POD and PAL activities were observed with $\mathrm{P} S+$ Trichoderma followed by ABA+ Trichoderma and SA+ Trichoderma). Biotic inducers are known to have eliciting activities leading to a variety of defense reactions in host plants in response to microbial infection, including the defense related enzymes and accumulation of phenolic compounds as well as specific flavonoids (Abd El-Rahman et al., 2012; Hussein et al., 2018 and Sarhan et al., 2018). Silicon-enhanced biochemical resistance is associated with increasing the activity of defense-related enzymes, such as polyphenoloxidase, glucanase, peroxidase, and phenylalanine ammonia-lyase (PAL) (Fauteux et al., 2005; Datnoff et al., 2007; Van et al., 2013). However, P S + Trichoderma was the most effective followed by $\mathrm{SA}+$ Trichoderma and ABA+ Trichoderma and they significantly enhanced PPO enzyme activity comparing with the control. On the other hand, the treatments with SA, PS and ABA alone were the highest in POD, PPO and PAL activities followed by ABA, PS and ABA, respectively. The activities of $\mathrm{POD}$ and $\mathrm{PPO}$ were reached the highest level at 4 days, then declined. Whereas, Trichoderma treatment was the least effective in this respect compared with other treatments comparing with the infected plants. These findings are in harmony with reports published by EL-Tanany et al., (2018), Khalil and Adbelghany (2021) and Prakash et al. (2021) as they found that, treating tomato plants with ABA, SA and Trichoderma before inoculation with $A$. solani increased the activities of peroxidase, Polyphenol oxidase [catechol oxidase] and phenylalanine ammonialyase and reduced the rates of leaf infection and disease index. Salicylic acid was endogenous signal for the activation of certain plant defense responses, including pathogenesis related gene expression, oxidative defensive enzymes, polyphenol oxidase (PPO), Catalase (CAT) superoxide dismutase, $\beta-1,3$ glucanase, peroxidase (POD) and phenylalanine ammonia lyase (PAL) and enhanced resistance to many pathogens such as A. solani, Botrytis cinerea, Clavibacter michiganensis subsp michiganensis, Ralstonia solanacearum and Meloidogyne javanica (Li and Zou 2017 and Wang et al. 2013). ABA treatment to tomato plants reduces early blight disease severity by triggering defense genes and defense related compounds viz., POD, PPO and PAL (Song et al., 2011, Wang et al., 2013 and Nassar and Adss, 2016). Our results indicate the positive relationship between the decrease of disease severity of early blight and increased activity of polyphenol oxidase, peroxidase and PAL enzymes, which is related to induction of induced systemic resistance activity in tomato plants against $A$. solani.

On the other hand, data showed that there were significant differences between all treatments in growth characteristics (fresh shoot, dry shoot, fresh root, dry 
root weight and total fruits weight / plant) under infection with $A$. solani. The obtained results are in accordance with those obtained by El-Shennawy and Abd El-All (2018), Khalil and Adbelghany (2021). The treatment with P S + Trichoderma, ABA+ Trichoderma and SA+ Trichoderma were the most effective they have the highest growth characteristics compared with the other treatments. No significant differences were detected between ABA+ Trichoderma and SA+ Trichoderma in the fresh shoot, dry shoot and fruits weight. This is in harmony with (Abay and Sheleme, 2011, and Abou-El-Hassan et al., 2020) as they reported that the potassium silicate application increases growth parameters of the potato plants. Trichoderma spp. as a biocontrol agents, they are known to reduce plant pathogenic assault and boost plant growth and yield by increasing growth hormones and the beneficial microbiome of the plant (Dubey et al., 2007) Improving the growth of plants that were treated with potassium silicate can be attributed to the role of potassium in many metabolic processes and acts as a catalyst or activator of certain enzymes into the plant, thus improving growth parameters of plants (Dubey et al. 2007; Khatabi et al. 2012).Tomato plants treated with antioxidants (salicylic acid, ascorbic acid, and boric acid) increased growth traits, plant height, leaf area fresh and dry weight, according to El-Shennawy, Abd El All. (2018) and El-Garhy et al. (2020).

The combination of potassium silicate and Trichoderma was the most beneficial, greatly increasing (chlorophyll "A" and "B") content when compared to control. At 4 days, the levels of chlorophyll "A" and "B" were at their peak, then began to fall. At 2 days postinoculation, the ABS+ Trichoderma therapy had the highest level of carotene concentration. This could be owing to potassium's active engagement in a range of physiological activities, such as photosynthesis, protein synthesis, and plant tissue water status maintenance (Ebert, 2009; Marschner, 2012). Also, silicon has a role in improving the chain of photosynthesis and preventing the deterioration of chlorophyll, where the action of silica bodies as windows allowed the light transmission to the mesophyll area (Epstein, 1999; Pilon et al., 2014). In this respect, Salim et al. (2014), Abd El-Gawad et al. (2017) and Abou-El-Hassan et al. (2020) demonstrated that foliar application of potassium silicate improved the vegetative growth parameters of potato plants. Mady (2009) and El-Shennawy and Abd El-All. (2018) reported that, application of salicylic acid increased photosynthetic pigments, total carbohydrates and crude protein concentrations in leaves of treated plants as compared with those of untreated ones on tomato plants. Improved photosynthetic capabilities of different plant species induced by various endophytic strains of Trichoderma due to the increase of photosynthetic pigments or gene expressions regulating chlorophyll biosynthesis, light-harvesting complex proteins were documented by Harman et al, (2021). Results also indicated that the chemical inducers applied have increased the number of Trichoderma in soil. Trichoderma was the highest rate of the number of cfu in treatment with PS+ Trichoderma cfu was $5.9 \times 10$, while the number of cfu in treatment with $\mathrm{ABA}+$ Trichoderma was $3.77 \times 10^{7}$ and the treatment with SA + Trichoderma was $3.68 \times 10^{7}$.

Genetically, PR1, PR2 and PR5 gene expressions increased in all treatments with chemical inducer of tomato cultivar compared the infection by A. solani alone, while the treatment with chemical inducer combined with Trichoderma were highest gene expressions compared with chemical inducer alone. P S + Tichoderma showed the highest PR1gene expression followed by ABA+ Trichoderma and SA+ Trichoderma at 8 di post inoculation, while PR2 and PR5 gene expressions reached the highest level with $\mathrm{P} S$ +Tichoderma followed by SA+Trichoderma and $\mathrm{ABA}+$ Trichoderma at $8 \mathrm{di}$ post inoculation. The highest PR1and PR5 gene expressions were found in the treatment with PS followed by SA alone. The PR3 gene expression was the highest in the treatment with ABA followed by PS alone. These findings matched those of Selim (2015). These findings suggested that inducing systemic defense mechanisms using mutualistic Trichoderma isolates like T10 could be one of the ways to combat Alternaria solani infection. The gene of PR1 expression was upregulated in leaves were treated by salacylic acid and absesic acid at one day after of inoculation with alternaria solani, which confirms the role of $\mathrm{SA}$ and $\mathrm{ABA}$ in systemic acquired resistance (Prakash et al., 2021). These findings are in agreement with our results. Meanwhile, Vivancos et al. (2015) found that the Arabidopsis were high resistant to infection with Golovinomyces cichoracearum than control plants when treated with $\mathrm{Si}$, and corresponded with higher expressions of PR1, PR2 and PR5 defense genes.

\section{CONCLUSION}

The present study confirmed that the treatment with chemical inducers combined with the bio agent Trichoderma harzianum have the potential to decrease disease severity of tomato early blight and to improved growth characters and photosynthetic pigments through different mechanisms of action including stimulation of defense-related enzymes and pathogen related proteins such as PR1, PR3 and PR5 gene can be involved in management of early blight disease. 


\section{REFERENCES}

Abay, A. and B. Sheleme, 2011. The influence of potassium application on the production of potato (Solanum tuberosum L.) at Kembata in Southern Ethiopia. J. Biol. Agric. Healthcare 1(1): 1-12.

Abay, A. and B. Sheleme. 2011. The influence of potassium application on the production of potato (Solanum tuberosum L.) at Kembata in Southern Ethiopia. J. Biol. Agric. Healthcare 1(1): 1-12

Abd-El-Rahman, S., M.M. Mazen, H.I. Mohamedand N.M. Mahmoud. 2012. Induction of defence related enzymes and phenolic compounds in lupin (Lupinus albus L.) and their effects on host resistance against Fusarium wilt. Eur. J. Plant Pathol., 134: 105- 116

Abou-El-Hassan. S., H. A. Metwaly and A. M. Ali. 2020. Efficiency of potassium and calcium compounds in gel formula to control early blight disease, improve productivity, and shelf life of potato. Egypt. J. Agric. Res., (, 98 (1):154-168.

Adie B.A. T, J. Pérez-Pérez, M.M. Pérez-Pérez, M. Godoy, J.J Sánchez-Serrano, E.A. Schmelz and R. Solanoa. 2007. ABA is an essential signal for plant resistance to pathogens affecting JA biosynthesis and the activation of defenses in Arabidopsis. Plant Cell 19:1665-1681

Ali, N., A. Ramkissoon, A. Ramsubhag and J. Jayaraj. 2016. Ascophyllum extract application causes reduction of disease levels in field tomatoes grown in a tropical environment. Crop Protection, 83: 67-75.

Anand, R, S. Kulothungan, S. Karthika, R. Sentila, and K. Bhuvaneswari. 2009a. Assay of chitinase and beta-1,3 glucanase in Gossypium hirsutum seedlings by Trichoderma spp. against Fusarium oxysporum. Int. J. Plant Sci., 4(1): 255- 258.

Anand, T., R. Bhaskaran, T. Raguchander, R. Samiyappan, V. Prakasam and C Gopalakrishnan. 2009b. Defence responses of chilli fruits to Colletotrichum capsici and Alternaria alternata. Biol. Plant, 53(3): 553- 559

Anonymous. 1967. Symposium on the Crop Losses. Rome, FAO, United Nations. Benítez, T., A. M. Rincon, M. C. Limon, and A. C. Codon (2004). Biocontrol mechanisms of Trichoderma strains. Int. Microbiol. 7:249-260

Bokshi, A., S. Morris, and B. Deverall. 2003. Effects of benzothiadiazole and acetylsalicylic acid on $\beta-1,3-$ glucanase activity and disease resistance in potato. Plant Pathol. 52:22-27.

Chaerani, R., G. Remmelt, P. Stem, E. Roeland and R.E. Voorrips. 2007. Assessment of early blight (Alternaria solani) resistance in tomato using a droplet inoculation method. Journal of General Plant Pathology: 96-103.

Chandrashekara, K.N., S. Manivannan, C. Chandrashekara and M. Chakravarthi 2012. Biological control of plant diseases, chapter 10 in Eco-friendly Innovative Approaches in Plant Disease Management. International Book Distributors Dehradun, Uttarakhand (India), pp 147166
Chin L.S., S.K. Singh, Q. Wang and S.F. Murray. 2000. Identification of Okadaic-acid-induced genes by mRNA differential display in glioma cells. J of Biomed Sci 7: 152-159.

Datnoff, L. E., W. H. Elmer, and D. M. Huber. 2007. Mineral Nutrition and Plant Disease. St. Paul, MN, The American Phytopathological Society

Dickerson, D.P., S.F. Pascholati, A.E. Hagerman, L.G.Butler, R.L. Nicholson. (1984). Phenylalanine ammonia-lyase and hydroxycinnamate: CoA ligase in maize mesocotyls inoculated with Helminthosporium maydis or Helminthosporium carbonum. Physiological Plant Pathology 25: 111-123.

Dubey S.C., M. Suresh and S.S. Birendra. 2007. Evaluation of Trichoderma species against Fusarium oxysporum f.sp. ciceris for integrated management of chickpea wilts. Biol. Control 40:118-127.

El-Garhy, H. A. S., F. A. Abdel-Rahman, A. S. Shams, G. H. Osman and M. M. A. Moustafa. 2020. Comparative Analyses of Four Chemicals Used to Control Black Mold Disease in Tomato and Its Effects on Defense Signaling Pathways, Productivity and Quality Traits .Plants 9, 808:120.

El-Shennawy, M.Z. and A.M. Abd El-All. 2018. Evaluation of Some Antioxidants against Tomato Early Blight Disease. Alex. J. Agric. Sci. Vol. 63, No.3, pp. 157-164.

EL-Tanany, M.M. Hafez, M.A., Ahmed, G.A. and M.H. Abd El-Mageed. 2018. Efficiency of biotic and abiotic inducers for controlling tomato early blight disease. Middle East Journal of Agriculture Research., Volume: 07|Issue.02April-June|2018Pages:650-670.

FAO (Food and Agriculture Organization). 2013. FAOSTAT; FAO: Rome, Italy; <http://faostat.fao.org/site/616/DesktopDefault

Fauteux, F., W. Remus-Borel, J. G. Menzies, and R. R. Belanger. 2005. Silicon and plant disease resistance against pathogenic fungi. FEMS Microbiol. Lett. 249:1-6.

George, M., S.R. Wu-Yun and M.A. Stillwell. 1977. Structure and synthesis of a new cyclopentenone derivative from Trichoderma album. Can. J. Chern., 55: 1610

Goel, N., K. Anukrati and P.K. Paul. 2017. Biocontrol of bacterial speck of tomato by aqueous extract of Tagetes erecta. Journal of Plant Protection Research SA//S (statistical analysis systems). 2014. Version 9.4 of the SAS system for windows. Cary. NC, USA: SAS Institute Inc.

Hammerschmidt R, J. Kuc. 1982. Lignification as a mechanism for induced resistance in cucumber. Physiological Plant Pathology 28: 227-233

Harman GE. 2006. Overview of mechanisms and uses of Trichoderma spp.

Phytopathology 96:190-194

Harman GE, C.R. Howell, A, Viterbo, I, Chet and M. Lorito . 2004. Trichoderma species opportunistic, avirulent plant symbionts. Nat Rev Microbiol 2:43-56 
Harman, G.E.; F. Doni; R.B. Khadka and N. Uphoff . 2021. Endophytic strains of Trichoderma increase plants' photosynthetic capability. J. Appl. 130: 529-546

Hirte, W.F.1969. The use of dilution plate method for the determination of soil microflora.The qualitative demonstration of bacteria and actinomycetes. Zentrall Bakteriol Parasitenkd Infektionskr Hyg:123(2):167-78.

Hussein, M.M.A., K.A.M. Abo-Elyousr, M.A.H. Hassan, M. Hashem, E.A. Hassan and S.A.M. Alamri. 2018. Induction of defense mechanisms involved in disease resistance of onion blight disease caused by Botrytis allii. Egyptian Journal of Biological Pest Control, 28: 80

Inbar, M., H. Doostdar, R.M. Sonoda, G.L. Leibee, and R.T. Mayer. 1998. Elicitors of plant defensive system reduce insect densities and disease incidence. J. Chem. New York, 24(1): 135-149.

Jagadeesh, K.S. and D.R. Jagadeesh. 2009. Biological control of early blight of tomato caused by Alternaria solani as influenced by different delivery methods of Pseudomonas gladioli B25. Acta Hort., 808: 327 - 332.

Keller, C., M. Rizwan, J. C. Davidian, O. S. Pokrovesky, N. Bovet and P. Meunier. 2015. Effect of silicon on wheat seedlings (Triticum turgidum L.) grown in hydroponic and exposed to 0 to $30 \mu \mathrm{M} \mathrm{Cu}$. Planta 241: 847- 860 .

Khalil, M.E.K.I. and R.E.A. Abdelghany. 2021. Effectiveness of Some Biotic and Abiotic Agents to Control Tomato Early Blight Disease Caused by Alternaria solani. Egyptian Journal of Phytopathology, Vol. 49, No. 1, pp 114-128.

Lee S.C. and S. Luan. 2012. ABA signal transduction at the crossroad of biotic and abiotic stress responses. Plant Cell and Environment 35: 53-60

Li, L. and Y. Zou. 2017. Induction of disease resistance by salicylic acid

and calcium ion against Botrytis cinerea in tomato (Lycopersicon esculentum). Emir J Food Agric 29(1):7882

Livak, K.J. and T.D Schmittgen. 2001. Analysis of Relative Gene Expression Data Using Real-Time Quantitative PCR and the 2(-Delta DeltaC (T)) Method. Methods, 25, 402408.

Mady, M.A. 2009. Effect of foliar application with salicylic acid and vitamin $\mathrm{E}$ on growth and productivity of tomato (Lycopersicon esculentum, Mill.). Plant J. Agric. Sci., Mansoura Univ., 34 (6): 6735 - 6746.

Mastouri, F., T. Björkman and G. E. Harman 2010. Seed treatment with Trichoderma harzianum alleviates biotic, abiotic, and physiological stressesin germinating seeds and seedlings. Phytopathology 100:1213-1221.

Mayer, A.M., E. Harel, R.B. Shaul. 1965. Assay of catechol oxidase: a critical comparison of methods. Phytochemistry 5: 783-789.

Molinari. S and P. Leonetti. 2019. Bio-control agents activate plant immune response and prime susceptible tomato against root-knot nematodes. PLoS ONE 14(12):1-17.
Nassar, A.M.K. and I. A.A. Adss . 2016. 2,4-Dichlorophenoxy acetic acid, abscisic acid, and hydrogen peroxide induced resistance-related components against potato early blight (Alternaria solani, Sorauer). Annals of Agricultural Science 61(1):15-23.

Pandey PK, KK. Pandey. 2002. Field screening of different tomato germplasm lines against Septoria, Alternaria and Bacterial disease complex at seedling stage. J. Mycol. Plant. Pathol. 32(2):233-235

Prajapati, H.N., R.K. Panchal and S.T. Patel. 2014. Efficacy of bio agents and biological interaction of Alternaria solani with phylloplane mycoflora of tomato. J. of Mycopathol. Res., 52: 81-86.

Ragab, M.M., M.M. Saber, S.A. El-Morsy and Abd A.R.M. El-Aziz. 2009. Induction of systemic resistance against root-rot of basil using some chemical inducers. Egypt. J. of Phytopathol., 37 (1): 59 - 70

Rodríguez, N. V., B. Kowalski, L. G. Rodríguez, I. B. Caraballoso, M. A. Suárez, P. O. Pérez, C. R. Quintana, N. González and R. Q. Ramos. 2007. In vitro and ex vitro selection of potato plantlets for resistance to early blight. J. Phytopath. 155:582-586

Sakr, N. 2016. The role of silicon ( $\mathrm{Si}$ ) in increasing plant resistance against fungal diseases. Hellenic Plant Prot. J., 9(1): $1-15$.

Sarhan, E.A.D.; E.M.M. El-Far and A.M.Y. Ebrahiem. 2018. Systemic resistance in snap bean (Phaseolus vulgaris L.) elicited by some chemicals and biotic inducers against white mold disease caused by (Sclerotinia sclerotiorum). Egypt. J. of Phytopathol., 46(2): 61-84

Selim, M. E. 2015. Effectiveness of Trichoderma Biotic Applications in Regulating the Related Defense Genes Affecting Tomato Early Blight Disease J Plant Pathol Microb. Volume 6 - Isue 10:1-7.

Simonetti, E. M.A. Carmona, M.M. Scandiani,' A.F a Garc1, A.G. Luque, O.S. Correa and K.B. Balestrasse 2012. Evaluation of indigenous bacterial strains for biocontrol of the frogeye leaf spot of soybean caused by Cercospora sojina. Lett. Appl. Microbiol., 55(2): 170-173.

Simonetti, E., M.A. Carmona, M.M. Scandiani, A.F. Garci'a, A.G. Luque, O.S. Correa and K.B. Balestrasse. 2012. Evaluation of indigenous bacterial strains for biocontrol of the frogeye leaf spot of soybean caused by Cercospora sojina. Lett. Appl. Microbiol., 55(2): 170-173

Song W., X. Ma, H. Tan and J. Zhou. 2011. Abscisic acid enhances resistance to Alternaria solani in tomato seedlings. Plant Physi and Bioch 49: 693-700.

Song,W., M. Xinrong and a. J. Zhou. 2011. Abscisic acid enhances resistance to Alternaria solani in tomato seedlings. Plant physiology and biochemistry: PPB.

Prakash.N., K. Vishunavat, G. T. Khan and P. Prasad. 2021. SA, ABA and Pseudomonas fluorescens elicit defense responses in tomato against Alternaria blight. Journal of Plant Biochemistry and Biotechnology. 30(1):13-25.

Sood, N., B. S. Sohal and J. S. Lore. 2013. Foliar application of benzothiadiazole and salicylic acid to combat sheath blight disease of rice. Rice Sci., 20: 349-355 
Strunz, G., W. Ren, M. Stillwell, and Z.Valenta. 1977. Structure and synthesis of a new cyclopentenone derivative from Trichoderma album. Can. J. Chem., 55: 2610-2612.

Talebi, S., A. Majd, M. Mirzai, S. Jafari and M. Abedini. 2015. The study of potassium silicate effects on qualitative and quantitative performance of potato (Solanum tuberosum L.). Biol.Forum Int. J., 7(2): 1021-1026.

Tarabih, M.E., E.E. El-Eryan and M.A. El-Metwally. 2014. Physiological and pathological impacts of potassium silicate on storability of Anna apple fruits. American Journal of Plant Physiology, 9(2): 52-67

Uddin, M. N., U. u. Rahman, W. khan, N. Uddin and M. Muhammad . 2018. Effect of Trichoderma harzianum on tomato plant growth and its antagonistic activity against Phythium ultimum and Phytopthora capsica. Egyptian Journal of Biological Pest Control 28:32
Van Bockhaven. J., D.D. Vleesschauwer and M. Hofte. 2013. Towards establishing broad-spectrum disease resistance in plants: silicon leads the way. J. Exp. Bot., 64(5):12811293

Van, B. J., D. De Vleesschauwer and M. Hofte. 2013. Towards establishing broadspectrum disease resistance in plants: silicon leads the way. J. Exp. Bot. 64:1281-1293.

Vivancos, J., C. Labbe, J. G. Menzies, and R. R. Belanger. 2015. Silicon-mediated resistance of Arabidopsis against powdery mildew involves mechanisms other than the salicylic acid (SA)-dependent defence pathway. Mol. Plant Pathol. 16: 572-582.

Wang Y, X. Tao, X.M. Tang, L. Xiao, J. Sun, X..F Yan, D. Li, H..Y Deng and X..R Ma. 2013. Comparative transcriptome analysis of tomato (Solanum lycopersicum) in response to exogenous abscisic acid. BMC Genomics $14: 841$

Wintermans, J.E.G. and A. De Mots. 1965 Spectrophotometric Characteristics of Chlorophyll $a$ and $b$ and Their Phaeophytins in Ethanol. Biochimica et Biophysica Acta, 109:448-453 


\section{الملخص العربي}

تأثير حمض الأبسيسيك وحمض الساليسيليك وسيليكات البوتاسيوم والتريكودرما كعامل مكافحة حيوى

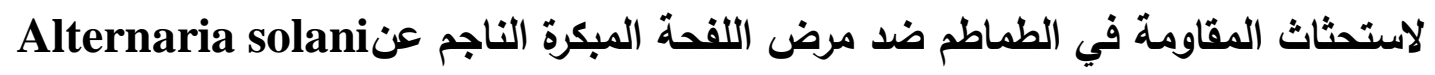

ابراهيم احمد عدس، غنيم محمد عامر ، شكري رمضان بيومى، اسيا رشاد عيد

في هذه الدراسة أردنا أن نرى كيف أثرت ثناثة محفزات بمعاملة . A. solani نشادة نشاط إنزيمات POD و PPO و

PAL والتعبيرات الجينية PR1 و PR2 و PR5 بشكل كبير في

كيميائية هى حمض الأبسيسيك وسيليكات البوتاسيوم

جميع المعاملات مقارنة بالمعاملة بواسطة A.solani والكنترول

وحمض الساليسيليك مختلطة مع التريكودرما على شدة

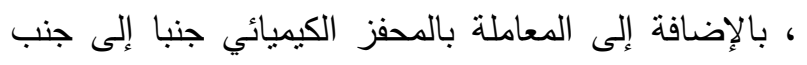

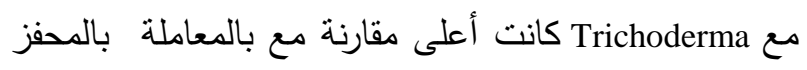
مرض اللفحة المبكرة في الطماطم ، وكذللك بعض خصائص النمو والقدرة على التمثيل الضوئي والإنزيمات المتعلقة

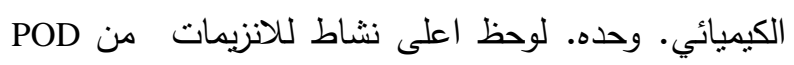

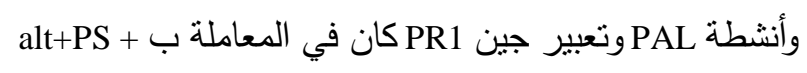

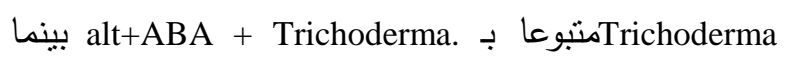

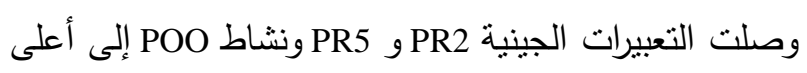
بالدفاع وتحليل التعبير الجينى لجينات PR1 و PR3 و PR5 ، كذلك تأثثرها على كثافة الترايكوديرما. وكانت النتائج:

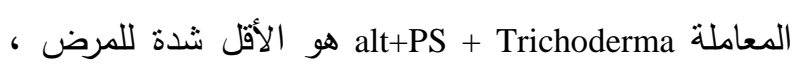
alt+SA + تليها alt+PS + Trichoderma مستوى بالمعاملة alt+ABA + Trichoderma. gTrichoderma كان اعلى كثافة لعدد اللتريكودرما عند cfuichoderma PS Trichoderma cfu المعاملة بـ

الكلمات الدالة: طماطم، لفحة، الترناريا، التريكودرما، مستحثات، انزيمات، التعبير الجينى. يليه alt+ABA + Trichoderma ، وكان معاملة Trichoderma أعلى كثافة للمرض مقارنة بمعاملة A. وكانت Alt+P solani. alt+SA + galt+ABA + Trichoderma $g$ + Trichoderma

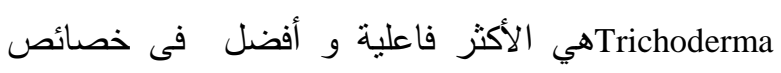

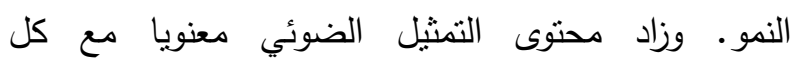
المعاملات بالمحفز الكيميائي و T. harzianum مقارنة بمعاملة alt+PS + Trichoderma كان A. solani. بو الأكثر فاعلية حيث عزز بشكل كبير محتوى الكلوروفيل مقارنة 